\title{
Dynamic RNA world
}

\author{
MICHAEL SATTLER ${ }^{1,2}$ \\ ${ }^{1}$ Institute of Structural Biology, Helmholtz Zentrum München, 85764 Neuherberg, Germany \\ ${ }^{2}$ Center for Integrated Protein Science Munich (CIPSM) at Department of Chemistry, Technische Universität München, \\ 85747 Garching, Germany
}

My research entered the RNA world when I joined the EMBL Heidelberg. During my doctoral and postdoctoral research I had focused on developing and applying solution NMR methods and studied protein structure and dynamics of the Bcl family proteins, which are important regulators of apoptosis. When I set up my own group at EMBL in 1997 I became quickly interested in the exciting research on RNA and its various roles in the regulation of gene expression. At EMBL I had the pleasure of meeting great and inspiring colleagues and RNA researchers, such as Juan Valcárcel, Elisa Izaurralde, Elena Conti, Stephen Cusack, Bertrand Seraphin, Anne Ephrussi, Matthias Hentze, and Iain Mattaj. I realized that there is much unexplored ground towards understanding the structural basis of protein-RNA interactions in gene regulation. So, my group started to work on elucidating how proteins recognize RNA and how these interactions regulate biological function. In these days the $R N A$ journal has been my entry to the RNA world and it remains an essential resource for exciting original research and insightful reviews on emerging topics.

With Juan Valcárcel (now at CRG Barcelona) and Angela Krämer (U Geneva) we began to study the structural basis of $3^{\prime}$ splice site recognition during the assembly of human spliceosomes. Specific recognition of the intron RNA involves the cooperation of multiple RNA binding proteins, such as Splicing Factor 1 and the U2AF heterodimer. The structural studies rationalized how cooperative and dynamic molecular interactions contribute to the regulation of eukaryotic premRNA splicing We also became interested in understanding the role of protein-protein (i.e., UHM-ULM) interactions in the regulation of alternative splicing. We also had fruitful collaborations with the labs of Reinhard Lührmann (MPI Göttingen) and Utz Fischer (Uni Würzburg) and I started to feel at home in the RNA Society.

After the discovery of RNA interference by Mello and Fire many groups including Elisa Izaurralde's and mine began structural analyses aimed at understanding the molecular mechanisms of posttranscriptional gene regulation by siRNAs

\footnotetext{
Corresponding author: sattler@helmholtz-muenchen.de

Article and publication date are at http://www.rnajournal.org/cgi/doi/ 10.1261/rna.050971.115. Freely available online through the RNA Open Access option.
}

and miRNAs. Structural biology demonstrated how the unique molecular features of siRNAs, i.e., their distinct $3^{\prime}$ and $5^{\prime}$ termini and size, are specifically recognized by Argonaute and Dicer proteins, and also by viral proteins that inhibit the RNAi response of the host. Important progress and insightful review articles published in the RNA journal helped to keep up with the fast pace in discoveries made.

One focus of current research in my lab aims at understanding the complex structural mechanisms underlying mRNA processing during gene regulation. An important challenge in the field is deciphering the splicing code, i.e., understanding the temporal and spatial regulation of premRNA splicing by the combinatorial action of multiple RNA binding proteins (RBPs) and RNA cis-elements. Recent work by the Frey, Blencowe labs and others is beginning to unravel the complexity of the code. At the structural and molecular level, this involves the cooperative action of multiple RBPs that bind to the pre-mRNA. My group would like to understand how the weak and not very specific interactions between trans-acting RBPs and cis-acting sequence motifs contribute to the complex mechanisms of alternative splicing regulation. Taking advantage of our expertise in complementary structural biology methods (NMR, small angle scattering, crystallography) we study the important roles of cooperative binding and conformational dynamics in protein-RNA recognition. Conformational flexibility is inherent to multi-domain RNA binding proteins, i.e., where individual domains are connected by flexible linkers. For example, we reported in 2011 that RNA binding by splicing factor U2AF involves a functionally important dynamic equilibrium between open and closed states of its tandem RRM domains (that are connected by a flexible linker) rather than a simple docking of protein and RNA. It is reasonable to expect that, at the molecular level, cooperative and dynamic RNA interactions add to the complexity of the splicing code and mRNA processing in general. We hope that we can further contribute to understanding these mechanisms in the future.

The RNA journal remains a great and valuable resource for the latest discoveries in RNA research and for publishing our

(C) 2015 Sattler This article, published in $R N A$, is available under a Creative Commons License (Attribution-NonCommercial 4.0 International), as described at http://creativecommons.org/licenses/by-nc/4.0/. 
own results. I personally value the insight provided by reviews written by experts that help keeping up with this fast moving field. A gratifying feature of the journal is that its editors and reviewers are genuinely interested experts who appreciate and understand the important roles of RNA in biology.

It is fascinating to see how RNA science has changed over the 20-year existence of the RNA journal. The CRISPR RNA revolution and the largely unexplored functions of long non-coding RNAs (lncRNAs) are just emerging.
Certainly, there are many more surprises ahead of us. The RNA Society and Tim Nilsen as the Chief Editor of the $R N A$ journal are to be congratulated for providing this essential resource and discussion forum for the community. The society and its journal will continue to flourish and support an inspiring, collegial community of RNA researchers. We all can be proud of being part of this endeavor. I am looking forward to reading about the next frontiers of RNA research in the journal. 

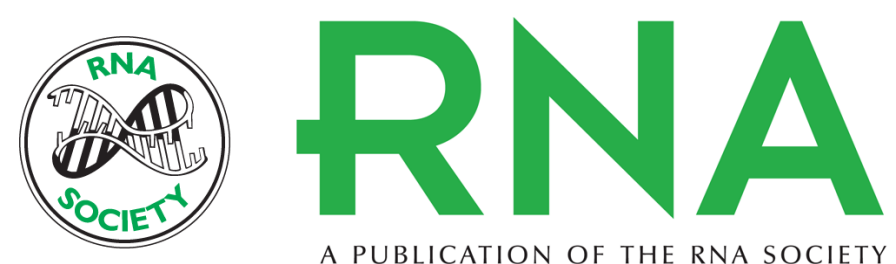

A PUBLICATION OF THE RNA SOCIETY

\title{
Dynamic RNA world
}

\author{
Michael Sattler
}

RNA 2015 21: 727-728
Open Access Freely available online through the RNA Open Access option.
Creative This article, published in RNA, is available under a Creative Commons License Commons (Attribution-NonCommercial 4.0 International), as described at License http://creativecommons.org/licenses/by-nc/4.0/. Email Alerting
Service

To subscribe to RNA go to:

http://rnajournal.cshlp.org/subscriptions

(C) 2015 Sattler; Published by Cold Spring Harbor Laboratory Press for the RNA Society 